\title{
The Problematics of the Import of Waste and the Recycling Sector in Albania after 1990
}

\author{
PhD. Mariglen Sherifaj \\ "Eqrem Çabej" University, Department of Geography, \\ Faculty of Education and Social Sciences, Gjirokastër, Albania \\ Email:mariglens@yahoo.com
}

Doi:10.5901/ajis.2016.v5n3s1p393

\begin{abstract}
Recently in Albania there is an ongoing and heated debate concerning the import of wastes of "the Green List". Basically the entire spectrum of our society, such as politicians, experts and civil society leaders are involved in this debate. The various interest groups involved don't just argue about the profits our economy and the environment stand to make from the recycling industry, but about the fact how controlled is the imported wastes, will they be treated according to the international standards, will they pose a threat to the wildlife, etc. In a country like Albania where until a few years ago the issue of wastes, as they are called in everyday speech, has been a big one; wastes were present everywhere, in the streets, city centres, rivers banks, along the coastline, even in some protected areas it is difficult to admit that recycling will proceed at the same pace as in the developed countries, which in turn display sharp differences among themselves as well. According to Eurostat in 2013 there was a big difference among the member states of the EU regarding recycling. Germany has the highest percentage of recycled municipal solid waste, at $64 \%$ compared to $3 \%$ in Romania while the EU recycling average is about $28 \%{ }^{1}$ In our country the development of the recycling industry is fraught with serious issues and may result in unwanted side effects given the fact $70 \%$ of it is imported meanwhile our national waste goes untreated, the environmental standards are not met and the proper infrastructure is missing.
\end{abstract}

Keywords: Green List, municipal solid waste, recycling, environmental standard, landfill

\section{Yes \& No about the Import of Wastes}

Once we heard the news that Albania can import waste we raised some questions. Is our country can be an example of success in processing treatment of waste? Does our country be a state of the technology and science in differentiation and treatment of waste? Does Albania be a major producer of wastes, industrial, toxic, inert, organic materials wastes etc.? What are the priorities of the Albanian economy in the future, the recycling industry or the development of tourism sector which requires a clean environment with natural ecosystems intact?

These questions go through mind of environmentalists, economists, specialists who have deep knowledge about the phenomena of various environmental problems, but also to those people who think they have done the best for this country where next generations will have the chance to live in a cleaner and more developed Albania and not in a place turned into a garbage deposit.

Industrialized countries are faced with the problem of wastes decades ago and one of the solutions used for the treatment of wastes was minimization or recycling process. They see recycling as a necessary evil which in addition to economic benefits, reduces pollution, the volume of waste destined for landfills, but can have consequences on the environment or human health if are used wastes that does not belong only to the Green List².

In Albania there is a diversity of opinions about waste and recycling industry. On one hand civil society and environmental organizations see them as a threat to the environment, on the other hand governments that are destinated to be changed often see it as a part of the business and overestimate them considering recycling as the key step to successful development of the economy, jobs etc. This group goes even further with the idea that the wastes that our country produces in a year does not meet the capacity of the recycling factories so they are looking to open doors to the

\footnotetext{
1 http://ec.europa.eu/environment/waste/eventspast/pdf/Muncipal\%20waste\%20Conference\%20Final\%20Report.pdf Separate Waste Collection in the context of a Circular Economy in Europe pg 6, year 2016,

${ }^{2}$ http://www.kohajone.com/2016/09/30/ green wastes from scraps and pig hairs to kerp and cannabis, here are the wastes that are mentioned to be imported in Albania
} 
import of wastes. In the trap of this demagogy of Albanian institutions have also fallen, geologist specialists, botanists, ecologists, hydrologists, climatologists, etc. who know very well that our country has specifications that make it impossible to import wastes from other countries. Here we can mention some of them:

a. Our country has a very small area and does not have unoccupied space which can be made available for the recycling industry which operates despite technological level and can not be considered $100 \%$ resulting from the ecological or human society. This makes it impossible to directly or indirectly nonexposure of human society to wastes that cause pollution despite the fact where is its location in landfills, factories, landfills etc. This issue is different in other countries that have thousands km2 wildernessor inhabitated spaces. Someone must say that waste generated in Albania are few compared to those expected to be imported so that it does not seem reasonable that our country becomes a repository of wastes coming from other countries despite the economic benefits of their recycling. If take in consideration figures how much wastes are produced in Albania (round 1 million tons/year) in neighbouring countries for example in Italy such amount is produced from Napoli, Torino, or Milano ${ }^{3}$ which have a population almost the same with Albania population.

b. Geological construction of our country with about $23 \%$ consists in carbonate rocks that are permeable and soluble shows that water wasted from manurex, waste residue can freely move from areas where performed recycle toward residential areas or territories operates where human society have its activities

c. Even hydrography with its elements appear more sensitive to pollution caused by pre recycled or recycled products which intentionally or not may accumulate, circulating through her arteries a source of pollution, a branch river, stream, etc. which can lead to contamination of the watershed and consequently to the settlements located in that territory. Here we can mention the rivers Gjanica, Erzen, Ishmi etc ${ }^{4}$ which are known for high pollution level and crossing of areas with density of population.

d. Since Albania is characterized by a large number of protected areas and high biodiversity, building factories or dumping of recycling waste by them would damage the national assets or ecological, economic, tourism elements which we have inherited over the centuries. Suffice it to mention the fact that $1 / 3$ of the greatest cities of the world as Melburn, Rio de Janiero, Budapest, Singapore, New York, etc. they take drinking water from hydrographic basins that are located in protected areas ${ }^{5}$ to understand that these are ecologically pure oasis of great importance to the living man and the world in general.

e. Does not it seem paradoxical fact that our country until 2004 due to lack of technology to send Persistent Organic Pollutants (POPs) in European countries of origin to be destroyed them, and now imports waste to be recycled? Although now it is not about POPs, as they are prohibited by the Stockholm Convention ${ }^{6}$ but waste which are part of the Green List, this example of use analogy shows that our country doesn`t have adequate capacity to develop proper recycling technology and industry.

f. Does our health and our offspring is fully guaranteed if we use recycled products? This question can hardly get respond from the science. Cases are not uncommon that even scientists have fallen into the trap of those products or inventions that have made themselves. Suffice it to mention POPs (Persistent Organic Pollutants), CFC (kloroflorocarbon), asbestos, chemicals or a part of that counted on 80000-1000007 which have been used for decades in developed countries, (already they have been declared harmful after leaving the consequences to the environment, or humans), to understand that those who give guarantees for products recycled which are not safe. Even the separation of waste at source (organic, plastic, matalike, glass, etc.) is a practice of late compared to the recycling industry. So even science has failed and will not ever come to know all the secrets of knowledge. To be sure we suggest that waste recycling Green performed by the most industrialized countries with a strong law to protect the quality of the environment or at least each country to recycle waste that produces within its territory carrying negative and positive consequences in treatment of waste.

\footnotetext{
${ }^{3}$ Municipal Solid Waste Management in Milan, Separate Waste Collection in the Context of a Circular Economy in Europe, Bruxelles, January 29th, 2016, http://municipalwasteeurope.eu/sites/default/files/6.Danilo\%20Vismara.pdf

4 United Nations Economic Commission for Europe, Albania Environmental Performance Reviews, pg 84, New York and Geneva, 2012 , http://www.unece.org/fileadmin/DAM/env/epr/epr_studies/Albaniall.pdf

${ }^{5}$ Meçaj.N, Applied Geography,pg 239, Tiranë 2004, TOENA

${ }_{6}$ Ziu.T, Geography of territory regulation pg 158, Tiranë 2009, Pegi

${ }^{7}$ Rockstrom. J, Steffen. W, Noone. K, etc, Planetary Boundaries: Exploring the Safe Operating Space for Humanity http://www.ecologyandsociety.org/vol14/iss2/art32
} 
g. Where will we use recycled products in the future and how waste can be recycled again? If we compare this issue with the developed countries which are extremely careful in handling the waste, the frequency of their use and intended that they will have after recycling, in our country is difficult to say whether raw materials, tools etc. has or not a story before recycling. The case of using an advance the technology from a company in Sweden where plastic bottles recycled before, parsed their history through the use of laser rays ${ }^{8}$ it is a very good example to see our country's differences with developed countries.

\section{Situation of Wastes in Albania and Their Recycling Potential}

Before we start analyzing this issue, we must clarify what are garbages and wastes and how to classify them.

The waste is defined as a substance or object which the holder discards or intends or is required to discard. A substance or object can not be simply a product wastes but only when faced with these conditions ${ }^{9}$

- Further use of the substance or object is safe;

- The substance or object can be used directly without any further processing

- The substance or object is considered as an important part of the manufacturing process

- A further use is lawful, which means that a substance or object meets the requirements for environmental protection and health of a product for a specific use and that does not cause environmental damage or human health.

While trash (broader concept of waste) are the waste that is not recycled but deposited in landfills, burned in crematoria and destroyed through different technological processes. The developed world divides waste into different categories according to the list: Green, Orange and Red. Green waste list are regarded as non-hazardous but if they somehow mixed with hazardous wastes listed in the Red list.

The high noise being made in our country has to do with the import of Green List wastes for recycling purposes which listed 17 types $^{10}$ from 21 kinds part of Green List in EU. These residues have different origins from where can be mentioned generated waste, commercial, industrial, urban waste, etc. where the latter issued the greatest volume of recyclables.

Albania during the transition has maintained a bitter taste from waste which has become a nation wide concern. Increasing the amount of waste over the years unprocessed and transported in time, burning of the waste without any criteria and environmental standard has caused major environmental problems.

This progressive increase of waste which is linked to a number of factors such as growth of population, increased consumption, the spatial movement of the population, the growth of cities, uncontrolled construction, poor management of the companies that deal with waste, unprocessing of wastes through recycling etc.

Even neglecting from government to process wastes in time and according to environmental standards, etc. legitimized in some way a part of the thoughtlessness of the Albanian citizens wherever we lay wastes to making harder their collection and management. So huge was the spread of wastes that until a few years they were found in the streets, and towns, river beds, along the coastline and even in protected areas or tourist spots etc. Agony of 25 years in solving this problem has created a negative psychosis among the population for waste which are considered harmful, regardless of their type may even say that they have weakened our perception of aesthetics and beauty. This mentality has affected the spirit of resistance against the import of waste, seeing this as a dangerous economic activity.

If we take in cosideration general quantity of wastes generated from our country in a year we can find that it is increased progressivly during the period 2003- 2013. Figure 1 . The same thing it is noticed about urban wastes which are the main Green wastes which are destinated for recycling while the inert wastes seems to have a inconstancy related to their quantities among the years.

Despite the upward trend of wastes in our country their amount is small compared with developed countries.

\footnotetext{
${ }^{8}$ https://hbr.org/1992/03/how-europes-companies-reposition-to-recycle\#, Cairncross, F, How Europe,s companies reposition to recycle, Harvard bussines review, year 1992

${ }^{9}$ http://www.riciklimi.al/uploads/documents/424728857-1351123004.pdf, Abanian National Strategy on wastes, 25 May 2010

10 http:/www.balkanweb.com/site/lista-e-gjelber-nga-skrapet-dhe-qimet-e-derrave-tek-kerpi-i-kanabisit-ja-mbetjet-qe-pritet-te-importohenne-shqiperi/, Sinanaj.I, Green List/ from scraps and pig hairs to kerp and cannabis The kind of wastes which mentioned to be imported in Albania, September 2016
} 


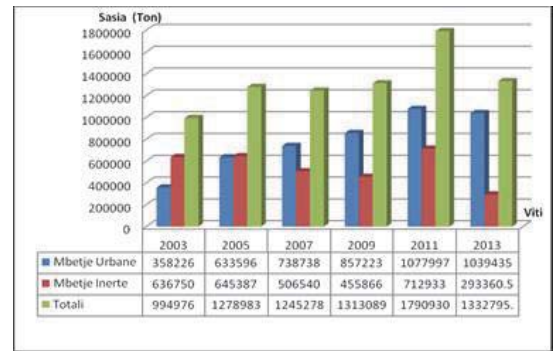

Figure 1. Urban and solid wastes in Albania during the period 2003-2013 (INSTAT ${ }^{11}$ )

This is also the average amount of waste per capita that Albania produces about half the amounts of countries belonging to the Organization for Economic Cooperation and Development (OECD) ${ }^{12}$ and generates less waste per person than neighboring countries such are Macedonia, Bosnia \& Herzegovina, Croatia etc (Fig. 2). In 2012, quantity of urban wastes per inhabitants resulted to be $332 \mathrm{~kg} /$ inhabitants/year while in 2009 it was $229 \mathrm{~kg} /$ inhabitants/year $^{13}$.

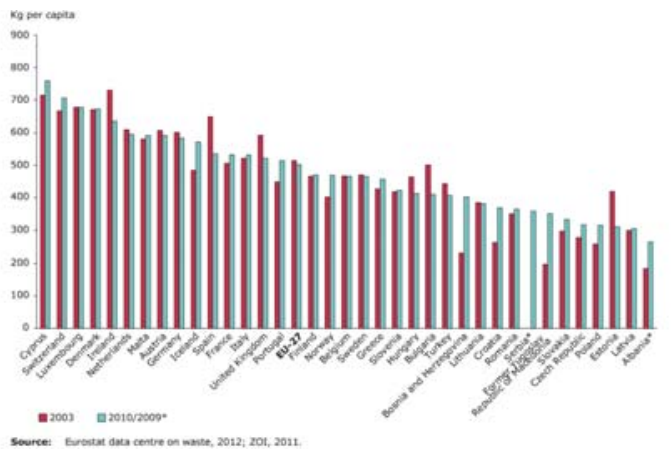

Figure 2. Trend in generation of municipal waste in the EU, EFTA countries, Turkey and Western Balkan countries, 2003 and $2010^{14}$

We made evident this problem to understand the perception and our behavior for wastes is not the same with developed countries which have provided solutions to their processing decades ago. According optics developed countries the import of waste is a normal economic activity in order to meet the recycling industry's capacity. The problem is how these wastes are controlled; do they present a risk to the environment and its components? Do they mix with hazardous waste etc.? Since our country has no capacity and does not meet environmental standards and infrastructure for waste treatment why should import instead of exporting?

\section{Recycling World History}

Judging about the phase that is our country's refering to recycling industry should be given a brief history of this industry. It is known that recycling was born and developed from the need to save sources of raw materials and by the need to minimize pollution which has become a global phenomenon and of multilateral consequences. Although recycling looks like a modern concept introduced by the environmentalist movement in the 1970s, it has been applied in thousands of years. It is said that the statue Giant of Rhodes used scrap pieces ${ }^{15}$.

Before the industrial revolution recycling industry had a negligible share in the world economy. Even the few

\footnotetext{
11 http://databaza.instat.gov.al/pxweb/sq/DST/START_EN/EN0009/?rxid=e618a59a-05b3-41f5-b514-158dabf25685

12 http://www.riciklimi.al/uploads/documents/424728857-1351123004.pdf, Albanian National Strategy on wastes pg.20, 25 May 2010

13 http://www.mjedisi.gov.al/files/userfiles/Monitorim_Mjedisor/Mbetjet.pdf, Wastes, pg 2, year 2013

14 European Environment Agency, Material Resources and Waste -2012, The European Environment State and Outlook 2010, http://www.eea.europa.eu/soer/synthesis/synthesis , pg 24, Luxembourg 2012

15 http://www.economist.com/node/9249262, The truth about recycling , June 2007
} 
workshops that existed in different countries of the world were far from primitive and modern concepts for recycling. Besides metals that have a history of early recycling, recycled paper is much later followed from plastic, glass waste. Recycling paper it date in 1031 in Japan. While prior to recycling factories were built in 1690 in Ritenhouse near Philadelphia and in 1801 England used to produce paper from fibers of cotton and flax ${ }^{16}$.

During the industrial revolution the great demand for raw materials made it necessary recycling as need for it was not everywhere able to be fulfilled. Reducing costs of production and trade at low prices motivated people throwing away equipment, machinery, tools, etc. and buy new, more modern which prompted increased recycling since the wastes and resources were reduced.

At the end of the XIX century and early XX -century in industrialized countries urban and industrial wastes started to become a concern for causing pollution. They were created various organizations that had in their focus waste and ways of processing them. So in 1913 it was created the American Institute of Scrap Recycling Industry (AISRI) ${ }^{17}$ etc.

In these years it was introduced for the first time in New York by George. E.Waring system of waste treatment and recycling among other things it was emphasized the separation of paper from organic waste, metals and wood in separate containers. This important event is added to the opening of the aluminum recycling plant in Chicago and Cleveland in $1904^{18}$.

During World War I, 1929-1933 (Economic Depression), recycling industry had a qualitative leap after it was realized economic expediency and positive environmental impact that recycling had. During this period rolled slogan "Don't waste the waste." Only in America was recycled thousands of tons of paper from old books and newspapers, parts of old clothing, etc. were reused. This trend was observed in the aluminum industry where cans were produced with smaller dimensions and smaller weight from 3 to $1 / 2$ ounce and aluminum wastes were recycled several times ${ }^{19}$.

Even during World War II about 400,000 volunteers and millions of workers were part of the recycling industry helping with food and logistical respective armies in camps. Proper administration, conservation and recycling and re use of tin, rubber, aluminum and other materials had been taken very seriously.

During the "Boom Economy" recycling trends began to weaken. This lasted until 1970 when Earth Day recycling became the main topic to be discussed. In later years the recycling industry faced numerous controversies however it had increased progressively year by year ${ }^{20}$. Recycling propaganda is already done anywhere in schools, religious Institutions, various organizations up to awarness of humble people. In 1973 Nathaniel Wyeth invented plastic bottles made of polyethylene terephthalate (PET). They replaced glass bottles which are difficult to be recycled ${ }^{21}$.

In 1991, Germany made history in the recycling industry by giving the responsibility of the recycling totally to industrialist. It created the Germany Dual System (GDS) to organize a company management system of waste separation. Later many European countries followed the Germany model. Here we can mention ELOPAK the Norwegian company which was forced to pay the extra cost for recycling because its cartons for beverage produced were difficult to recycle because they were coated with plastic laminate.She collaborated with the Research Center SINTEF and later with the TiTech Company getting modern machinery for waste separation and selection. The working principle of this device has to do with technological differentiation of waste by halogen bulbs which use infrared beam with different wave length. Processes performed by this device have an accuracy of up to $98 \% 22$.

Recycling already applied everywhere but marked differences between countries and even between administrative units within a country that are dictated by economic, technological, political development and above all how are waste from the population in various countries.

According to Eurostat data in 2013 there is a big difference between EU member states in the field of recycling. Thus Germany has the highest proportion of recycled urban waste 64\%, while in Romania this figure ranges around 3\% .The same is also noted for waste disposal in landfills where Germany depositing nearly $0 \%$ and Romania $97 \%$ while average throughout the $\mathrm{EU}$ is around $31 \% 23$.

\footnotetext{
${ }^{16}$ http://www.motorcityfreegeek.net/index.php?option=com_content\&view=article\&id=69\&/temid=78 A Brief History of Recycling

17 http://www.economist.com/node/9249262, The truth about recycling , June 2007

$18 \mathrm{http}: / /$ www.motorcityfreegeek.net/index.php?option=com_content\&view=article\&id=69\&/temid=78 A Brief History of Recycling

${ }^{19} \mathrm{http}$ ://www.motorcityfreegeek.net/index.php?option=com_content\&view=article\&id=69\&ltemid=78, A Brief History of Recycling

20 http://science.howstuffworks.com/environmental/green-science/recycling1.htm How Recycling Works

${ }^{21} \mathrm{http}: / /$ www.motorcityfreegeek.net/index.php?option=com_content\&view=article\&id=69\&/temid=78, A Brief History of Recycling

22 http://www.economist.com/node/9249262, The truth about recycling , June 2007

${ }^{23}$ http://ec.europa.eu/environment/waste/eventspast/pdf/Muncipal\%20waste\%20Conference\%20Final\%20Report.pdf Separate Waste Collection in the context of a Circular Economy in Europe pg 6, year 2016
} 
From history that we discussed above come to the conclusion that the recycling industry is as old as the problematic since knowledge of waste processing have never been full despite the positive impact on the economy, employment, saving of resources, reduce of pollution and improving the environmental quality although the latter is viewed with skepticism.

\section{Recycling Industry in Albania and Its Problems}

Following the example of developed countries in Albania in the '90s it began to flourish recycling industry. Recycling enterprises that were established started dealing with different waste treatment such as wood, paper, cardboard, plastic, metal etc. mostly harmless wastes that today are classified as Green List wastes.

In contrast to other countries where is paid great importance to the recycling industry to reduce waste generated within their territory, reducing pollution in addition to economic benefits, in our country was not paid proper importance to environment leaving stock wastes generated among years and taking raw materials from imports. So in Albania was neglected processing of domestic waste particularly urban wastes from which can be issued more than $50 \%$ of recycled materials and bio-wastes ${ }^{24}$. Such paradox which is observed in the recycling industry which relies on imports and very few wastes that were provided in the country shows that our country does not have the same approach with the developed countries in relation to waste management part of which is recycling.

Certainly the recycling businesses have their arguments related to this issue as misallocation of waste at source, poor management of enterprises dealing with the collection and transportation of waste, the desire to have multiple profits from recycling and not processing the wastes that were generated in our country. These reasons have pushed this business to take in consideration the import of wastes.

Related to the wastes import results that the oldest custom document made public it belong to 1993 when in Albania have been imported wastes from Italy and after were recycled. Some of the investments were modest but which had a low cost and less environmental rules than in neighbouring country, Italy 25.

Recycling industry during the last two decades has seen a partial development where are built a series of recycling fabrics which have gradually expanded activity.

Recycling factories are built near large urban centers like Tirana, Durres, Fier, Berat, Vlora, Shkodra, etc. and along the road axis Korçë -Elbasan-Tirana-Durres ${ }^{26}$. Such issue increases the chances that increase pollution affects for the environment of these geographic areas as they are with high density of population, are highly concentrated economic activities and a large number of circulating vehicles. Because they rely mainly on imports we recommend that they have to be built in sparsely populated areas and at customs points thus implementing the principle of proximity27.

During the period 2003-2004 started to take form a big project about recycling and elemination of wastes in Albania ${ }^{28}$. This was followed by a series of initiatives taken by the government, business community, environmentalists associations etc. Despite having spent over 10 years have not yet been achieved environmental standards in waste treatment, has not started massively separation of waste at source, the percentage of recycling in relation to waste disposal in landfills is too small far from developed countries even from countries in the region.

If we analyse the specific weight of wastes which are destinated to be recycled in our country we can say that is lower than average noticed in EU countries wich go up to $28 \% 29$.

In Albania in 2015 were recycled $20-25 \%$ of urban wastes, or 200000 tons from which 1000000 tons generated every year and the rest is destinated for the landfields $50-68 \%$, for burning $1.5 \%$, for export or is thrown outside the landfields. Table $\mathrm{N}=1$

\footnotetext{
${ }^{24}$ http://www.riciklimi.al/uploads/documents/publikime/509134401-1350603774.pdf Guri. M, Reduction, Reuse, Rcycling, 3R, Ecological method to process the urban wastes,pg 19, Tiranë 2008

${ }^{25} \mathrm{http}: / / w w w . g a z e t a e x p r e s s . c o m / o p e d / h i s t o r i a-e-v e r t e t e-e-i m p o r t i t-t e-p l e h r a v e-n e-s h q i p e r i-256701 /$, Fevziu.B, The real story of waste import in Albania 24 September 2016

${ }^{26}$ http://www.riciklimi.al/industria.php , Environmental Centre for Protection, Eduction and Rehabilitation (ECPER Center)

27 http://www.riciklimi.al/uploads/documents/424728857-1351123004.pdf, Albanian National Strategy about waste, pg 50, 25 May 2010

${ }^{28} \mathrm{http} / / / w w w . g a z e t a e x p r e s s . c o m / o p e d / h i s t o r i a-e-v e r t e t e-e-i m p o r t i t-t e-p l e h r a v e-n e-s h q i p e r i-256701 /$, Fevziu. .B, The real story of waste import in Albania 24 September 2016

${ }_{29} \mathrm{http}$ ://ec.europa.eu/environment/waste/eventspast/pdf/Muncipal\%20waste\%20Conference\%20Final\%20Report.pdf Separate Waste Collection in the context of a Circular Economy in Europe pg 6, year 2016
} 
Tab. 1: Processing of urban wastes ${ }^{30}$

\begin{tabular}{|c|c|c|c|c|c|c|c|c|c|c|}
\hline \multirow{2}{*}{ vieet } & \multicolumn{2}{|c|}{ Djegie plir energili } & \multicolumn{2}{|c|}{ Djegie plir eleminim } & \multicolumn{2}{|c|}{ Riciklime } & \multicolumn{2}{|c|}{ Depoztime ne landfille } & \multicolumn{2}{|c|}{ Hedhje jashte landillith } \\
\hline & Ton & \% & Ton & $\%$ & Ton & $\%$ & Ton & $\%$ & Ton & $\%$ \\
\hline 2013 & 940 & 0.1 & 82.734 & 8.8 & 225.638 & 24,0 & 475.721 & 50.6 & 155.127 & 16.6 \\
\hline 2014 & 6.144 & 0.5 & 38.095 & 3.1 & 265.439 & 21,6 & 779.112 & 63,4 & 140.093 & 11,4 \\
\hline 2015 & 21.706 & 1,5 & 35.875 & 2.5 & 357.548 & 25,3 & 970.157 & 68.6 & 970.157 & 2,0 \\
\hline
\end{tabular}

It should be noted that in early years when it was built recycling industry in our country the percentage of recycling waste was smaller compared to the storage and disposal of waste out of landfills, which should have been much higher than in the current period. Also we should note that waste destined for recycling do not come only from urban waste but also from industrial, commercial, construction wastes, etc.

Recycling plants process about $30 \%$ of domestic waste and $70 \%$ of imported wastes. Albania has the capacity to process 800000 tons of inorganic wastes per year. This shows that $1 / 3$ of them taken from local raw materials and more than $2 / 3$, or about 500,000 tons of wastes are imported from other countries. This is a disproportionate value taking in consideration amount of imports with exports which have a small weight. Picture $\mathrm{N}=3$.

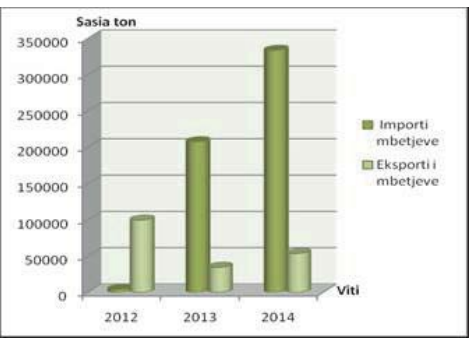

\section{Import and export of wastes in Albania during the period 2012-2014 (General Customs Directory)}

Recycling companies in Albania belong to the private sector. In 2015 operated round 110 companies which dealt with transporting, collection, processing and recycling while in 2009 there were round $60^{31}$ companies. $61 \%$ of these companies are small enterpresing where have been employed up to employees to each of them and only 13 companies have more than 80 employees $^{32}$

Tab. 2: Recycling industry $n$ Albania in 2015

\begin{tabular}{|l|c|c|}
\hline Waste stream & Companies & Number of Employees \\
\hline Plastic & 26 & 967 \\
\hline Metal & 15 stee $^{34}$ & 1327 \\
\hline Used oil and hydrocarbons" & 15 & 1362 \\
\hline Wooden products & $10^{35}$ & 186 \\
\hline Car machine & 21 scrap & 951 \\
\hline Letter & 10 & 172 \\
\hline Batteries & 4 & 130 \\
\hline Glass & 2 & 51 \\
\hline Electronics & 2 & $\mathrm{~N} / \mathrm{A}$ \\
\hline Other activities & 5 & 127 \\
\hline Total employment & $\mathbf{1 1 0}$ & $\mathbf{5 , 2 7 3}$ \\
\hline
\end{tabular}

30 INSTAT, Solid urban wastes in Albania pg 5, July 2016

${ }^{31}$ http://www.riciklimi.al/uploads/documents/424728857-1351123004.pdf, Albanian National Strategy about wastes pg 7, May 2010

32 ECAT, Strategy "Green Jobs: Employment in Waste Menagement and Recycling in Albania" Pg 51, Tiranë 2016

33 ECAT, Strategy" Green Jobs: Employment in Waste Menagement and Recycling in Albania"Pg 49, 32-34, Tiranë 2016

${ }^{34}$ http://www.riciklimi.al/uploads/documents/424728857-1351123004.pdf, Albanian National Strategy about wastes, pg 7, May 2010

${ }_{35}$ ECAT, Strategy "Green Jobs:Employment in Waste Menagement and Recycling in Albania" Pg 43,48, Tiranë 2016 
As conclusion seeing the prolonged problems of waste in our country we can say that the recycling business except the challenges such as provision of raw materials, fulfills the technological and environmental parameters etc. must give convincing evidence to the public that is part of the solution to pollution.

\section{Recommandation}

* Taking in consideration gaps in legal infrastructure, institutional, poor management of waste, the lack of experience in field of recycling, low awareness of population about waste types, ways of their treatment, etc. is needed a long period to allow imports waste in order that our country will be able to make adequate progress in these directions.

* Since the problem of waste is initially present in our country should be treated domestic waste, then we can open doors to the import of wastes.

* Should be taken detailed studies in order to determine precisely and in detail the places where wastes will be collected, treated or recycled considering the distance from residential areas, roads, protected areas and territories which consist of porous rocks. This requires not only the commitment of national or international institutions but also specialists such are geologists, geographers, climatologists, hydrologists, environmental engineers also various environmental associations.

4 A moratorium should be developed where to prohibit throwing of waste anywhere applying fines for individuals, businesses or entrepreneurs who fail to comply with environmental criteria. This can be achieved by sensitizing the population, creating the conditions and infrastructure for waste separation at source, efficient use of tax taken for cleaning, developing the curriculum that deal with environmental education, etc.

* Recycling plants should be built in territories that have minimal impact on the environment or human health.

* Should be paid great attention to recycling companies wich deal with handling or treatment of waste as these businesses are highly sensitive economic activities that can leave short-term or long-term effects on the environment or human health if they do not implement environmently rigorous standards. So is needed a continuous monitoring and a strict disperse of all stages that have to do with wastes and their treatment.

* From the above mentioned analysis we conclude that in Albania generate not large amounts of waste that are partly destined for recycling because they are not managed properly. For our country are raised two alternatives: a) the export of waste b) or recycling in Albania. If we apply the second alternative recycling industry should guarantee environmental standards, modern technology, import waste to supplement its capabilities which already has been done also need to handle the domestic wastes which for 25 years didn't get the proper attention.

\section{References}

Cairncross, F, How Europe,s companies reposition to recycle, Harvard bussines review, https://hbr.org/1992/03/how-europescompanies-reposition-to-recycle\#, year 1992

ECAT, Strategy "Green Jobs:Employment in Waste Menagement and Recycling in Albania",http://www.recp.al/wpcontent/uploads/2016/05/Strategy-on-Green-Job-Opportunity-Employment-in-Waste-Management-and-Recycling-in-Albania.pdf, Tiranë 2016

European Environment Agency, Material Resources and Waste -2012, The European Environment State and Outlook 2010, http://www.eea.europa.eu/soer/synthesis/synthesis, Luxembourg 2012

Fevziu..B, Historia e vërtetë e importit të plehrave në Shqipëri, http://www.gazetaexpress.com/oped/historia-e-vertete-e-importit-teplehrave-ne-shqiperi-256701/, 24 Shtator 2016

Grabianowski .E How Recycling Works, http://science.howstuffworks.com/environmental/green-science/recycling1.htm

Guri. M, Reduktim, Ripërdorim, Riciklim, 3R, Metoda ekologjike të trajtimit të mbetjeve urbane, http://www.riciklimi.al/uploads/documents/publikime/509134401-1350603774.pdf, Tiranë 2008

http://databaza.instat.gov.al/pxweb/sq/DST/START_EN/EN0009/?rxid=e618a59a-05b3-41f5-b514-158dabf25685

http://www.economist.com/node/9249262, The truth about recycling, June 2007

http://www.kohajone.com /2016/09/30/plehrat-e-gjelberta-nga-skrapet-dhe-qimet-e-derrave-tek-kerpi-i-kanabisit-ja-mbetjet-qe-pritet-teimportohen-ne-shqiperi

http://www.motorcityfreegeek.net/index.php?option=com_content\&view=article\&id=69\&ltemid=78, A Brief History Of Recycling

INSTAT, Mbetjet e ngurta urbane në Shqipëri, Korrik 2016, www.instat.gov.al

Meçaj.N, Gjeografi e Aplikuar, Tiranë 2004, TOENA

Ministria e Mjedisit, Mbetjet, http://www.mjedisi.gov.al/files/userfiles/Monitorim_Mjedisor/Mbetjet.pdf, viti 2013

Municipal Solid Waste Management in Milan, Separate Waste Collection in the Context of a Circular Economy in Europe, Bruxelles, 
http://municipalwasteeurope.eu/sites/default/files/6.Danilo\%20Vismara.pdf January 29th, 2016

Qendra Mjedisore për Mbrojte, Edukim dhe Rehabilitim (EPER Center) http://www.riciklimi.al/industria.php,

Qiriazi.P, Sala. S, Melo.V, Laçi. S, Bego.F, Ekosistemet karstike të Shqipërisë, Fan Noli, Tiranë 1999

Rockstrom. J, Steffen. W, Noone. K, etc, Planetary Boundaries: Exploring the Safe Operating Space for Humanity http://www.ecologyandsociety.org/vol14/iss2/art32

Separate Waste Collection in the context of a Circular Economy in Europe http://ec.europa.eu/environment/waste/eventspast /pdf/Muncipal\%20waste\%20Conference\%20Final\%20Report.pdf, year 2016

Strategjia Kombetare Shqiptare mbi Mbetjet, http://www.riciklimi.al/uploads/documents/424728857-1351123004.pdf, Maj 2010

United Nations Economic Commission for Europe, Albania Environmental Performance Reviews, pg 84, New York and Geneva, 2012, http://www.unece.org/fileadmin/DAM/env/epr/epr_studies/Albaniall.pdf

Ziu.T, Gjeografia e rregullimit të territorit, Tiranë 2009, Pegi 